\title{
Effect of Astaxanthin from Phaffia Rhodozyma on T cell Population and Responsiveness to Mitogen in Splenic Mononuclear Cells of Male Broiler Chicks
}

\author{
Tetsuya Takimoto, Kan Sato, Yukio Akiba and Kazuaki Takahashi* \\ Laboratory of Animal Nutrition, Graduate School of Agricultural Science, Tohoku University, \\ 1-1 Tsutsumidori-Amamiyamachi, Aoba-ku, Sendai, JAPAN 981-8555
}

\begin{abstract}
Effect of feeding astaxanthin (Ax) provided as Phaffia rhodozyma on $\mathrm{T}$ cell population and responsiveness to mitogen, concanavalin A (Con A) or phytohemaggulutinin (PHA), of splenic mononuclear cells (MNC) was determined in male broiler chicks. Chicks at 1 week of age, were fed ad libitum on diets containing 0, 20 or 100 ppm Ax for 7 days. Feeding the diet containing Ax decreased percentage of CD3-positive cells, an indicator of the $\mathrm{T}$ cell population in splenic lymphocytes. Feeding the diet containing $20 \mathrm{ppm}$ Ax decreased percentage of CD4-positive cells estimated as the indicator of helper $\mathrm{T}$ cells, but no modulation was observed by feeding the diet containing $100 \mathrm{ppm}$ Ax. Percentage of CD8-positive cells, an indicator of cytotoxic T cell, was not affected by feeding diets containing either 20 or $100 \mathrm{ppm} \mathrm{Ax}$. T cell proliferation stimulated with Con A was enhanced by feeding diet containing $20 \mathrm{ppm}$ Ax, but not affected by $100 \mathrm{ppm}$ Ax. Feeding diets containing 20 and $100 \mathrm{ppm}$ Ax enhanced the proliferation of splenocytes against PHA. Feeding diets containing Ax showed no effect on interleukin(IL)-2 mRNA expression in splenocytes stimulated by Con A estimated as the $\mathrm{T}$ cell proliferation promoting factor. IL-2 like activity was slightly, but significantly, decreased by feeding diet containing $20 \mathrm{ppm}$ Ax. IFN- $\gamma$ mRNA expression, estimated as a T cell activator under condition of Con A stimulation, was higher in chicks fed the diet containing $20 \mathrm{ppm}$ Ax. These results suggest that proliferation and cytokine expressions of splenic $\mathrm{T}$ cells in response to feeding Phaffia rhodozyma containing Ax were independent of the dietary Ax concentration or total Ax intake. The enhancement of $\mathrm{T}$ cell proliferation by feeding $20 \mathrm{ppm} \mathrm{Ax}$ might be caused by changes in IFN- $\gamma$ rather than IL- 2 production in the chick splenocytes.
\end{abstract}

Key words : astaxanthin, Phaffia yeast, chicken splenocytes, T cell responsiveness, T cell population

\section{Introduction}

In chickens, a red-pigmented yeast Phaffia rhodozyma containing high concentration of astaxanthin $(\mathrm{Ax})$ has been used as a dietary source to improve the pigmentation of broiler meats (Akiba et al., 2001) and egg yolk (Akiba et al., 2000). When Ax was ingested in broiler chicks, it was transported via plasma lipoprotein (mainly high density lipoprotein) and incorporated into tissues and organs (Takahashi et al., 2004). However, there is a little information available on physiological pro- perties of either Ax itself or Ax derived from the yeast in avian species although it has been reported that feeding of Ax prevented toxicity from aflatoxin in mule duckling (Cheng et al., 2001).

Certain nutrients have functionality to modulate innate and acquired immune responses in chickens as well as in mammals. In mammals, it has been reported that Ax increased an antibody productions to $\mathrm{T}$ cell-dependent antigens (Jyonouchi et al., 1995), resulted in changes in expression of antigen on membrane surface (Jyonouchi et al., 1991) and enhanced cytotoxic $\mathrm{T}$ cell activity resulting in mod-

Received : May 19, 2005, Accepted : October 24, 2005

* Corresponding author : Kazuaki Takahashi, Laboratory of Animal Nutrition, Graduate School of Agricultural Science, Tohoku University 1-1 Tsutsumidori-Amamiyamachi Aoba-ku, Sendai, Japan 981-8555

Tel : 022-717-8690 Fax : 022-717-8691 E-mail : taka@bios.tohoku.ac.jp 
ulated production of cytokine (Jyonouchi et al., 2000). Furthermore, Chew et al. (1999) reported that splenocyte proliferative responses to phytohemaggulutinin (PHA) were stimulated by Ax in mice although the increased $\mathrm{T}$ cell proliferation was not correlated with IL-2 production. Thus immunomodulatory effect of Ax has been partly demonstrated. However, if and how Ax affects splenic $\mathrm{T}$ cell proliferation in chickens has not been reported to date.

Responsiveness to mitogen and population of $\mathrm{T}$ cells are critical markers to represent most immune responses in animals. T cells express the cluster of differentiation (CD) molecules on their cell membrane and the detection of these molecules is useful to estimate function of T cells. CD3- (Chen et al., 1986), CD4- and CD8- (Chan et al., 1988) positive cells have been recognized as mature, helper and cytotoxic $\mathrm{T}$ cell, respectively. Interleukin (IL)-2 is an essential cytokine for fundamental immune processes in avian and mammalian species. IL-2 is a potent growth factor for a variety of cell types and plays key roles in the differentiation and the function of $\mathrm{T}$ cells, the development of B cells and the activation of natural killer (NK) cell (Lillehoj et al., 1992). Members of the interferon (IFN) family in cytokines are produced in response to various stimuli including foreign cells, bacteria, and viral antigens and IFN- $\gamma$ among the family serve as important regulators in the activation of lymphocytes and monocytes (Lillehoj et al., 1992). Thus, it has been believed that IL- 2 and IFN- $\gamma$ are critical modulators in cellular immune responses.

In the present study, in order to elucidate mechanism of $\mathrm{T}$ cell responsiveness to $\mathrm{Ax}$, effects of dietary supplementation of Phaffia rhodozyma containing high concentration of Ax on $\mathrm{T}$ cell population and responsiveness to mitogen were determined in splenic mononuclear cells (MNC) of male broiler chicks.

\section{Materials and Methods}

\section{Animals and Diets}

Male broiler chickens (Ross) were housed in a battery brooder with electric heater and fed on a commercial broiler starter diet until 7 days of age. Then chicks were selected and assigned to 3 dietary groups of 8 chicks with 4 replicates by keeping 2 chicks per cage. Birds were kept in each experimental cage in temperature-controlled room $\left(25^{\circ} \mathrm{C}\right)$. They were fed on a basal diet (CP 22.0\%, ME $3.15 \mathrm{kcal} / \mathrm{g}$, Table 1 ), the basal diet containing 20 or $100 \mathrm{ppm}$ Ax for 7 days ad libitum. The red yeast, Phaffia rhodozyma, was kindly provided by Mercian Corporation, Tokyo, Japan. The Ax content of the freeze-dried Phaffia yeast was $5.5 \mathrm{mg} / \mathrm{g}$ of yeast. In our previous experiment, chicks fed diets containing 50 or $100 \mathrm{ppm}$ Ax for 14 days deposited almost similar amounts of $\mathrm{Ax}$ in spleen (Takahashi et al., 2004). From this result, dietary concentration of $\mathrm{Ax}$ was set up at 20 and $100 \mathrm{ppm}$. At 14 days of age, after body weight and feed intake were recorded, 4 chicks fed on each diet were slaughtered by blood letting for sampling spleens.

\section{Preparation of Mononuclear Cell Suspension}

Mononuclear cells (MNC) were isolated from spleen by density-gradient centrifugation. Collected spleen was meshed and suspended in RPMI1640 medium (Invitrogen, Corp., Carlsbad, CA, USA) supplemented with $100 \mathrm{U} / \mathrm{m} l$ penicillin and $100 \mu \mathrm{g} / \mathrm{m} l$ streptomycin (Invitrogen, Corp., Carlsbad, CA, USA). The suspension was gently added on Histopaque-1077 (Sigma, St. Lois, MO, USA). Centrifugation was performed at $400 \times \mathrm{g}$ for $50 \mathrm{~min}$ at $10^{\circ} \mathrm{C}$. The boundary layers between the medium with meshed spleen cells and Histopaque-1077 were collected as MNC and the resulted MNC were washed with RPMI-1640 medium 3 times.

Table 1. Basal diet composition

\begin{tabular}{cc}
\hline \hline Ingredients & $(\%)$ \\
\hline Corn meal & 53.42 \\
Soybean meal & 37.35 \\
Soybean oil & 5.0 \\
$\mathrm{CaCO}_{3}$ & 1.03 \\
$\mathrm{CaHPO}_{4} \cdot 2 \mathrm{H}_{2} \mathrm{O}$ & 1.75 \\
$\mathrm{NaCl}$ & 0.33 \\
DL-methionine & 0.25 \\
Lysine-chloride & 0.04 \\
Vitamin-mix & $1)$ \\
Mineral-mix & 0.4 \\
\hline Crude protein & 0.43 \\
Metabolizable energy & $22 \%$ \\
\hline 1) See Akiba and Matsumoto $(1986)$.
\end{tabular}

1) See Akiba and Matsumoto (1986). 


\section{Flow Cytometry}

The expression of cell surface markers on the splenic MNC was investigated by immunofluorescence. The $5 \times 10^{6}$ cells in $100 \mu l$ in each analysis were stained with $0.25 \mu \mathrm{g}$ fluorescein-conjugated mouse anti-chicken monoclonal antibodies to CD3 (Southern Biotechnology Associates, Inc., Birmingham, AL, USA) or double stained with $0.025 \mu \mathrm{g}$ R- phcoerythrin-conjugated mouse anti-chicken monoclonal antibodies to CD4 (Southern Biotechnology Associates, Inc., Birmingham, AL, USA) and $0.25 \mu \mathrm{g}$ fluorescein-conjugated mouse antichicken monoclonal antibodies to CD8 (Southern Biotechnology Associates, Inc., Birmingham, AL, USA) for $30 \mathrm{~min}$ at $4{ }^{\circ} \mathrm{C}$ in a volume of $10 \mu \mathrm{l}$ antibody solution. After washed by phosphate buffered saline, samples were analyzed within 6 hours of preparation on a FACSCalibur ${ }^{\circledR}$ flow cytometer (Becton Dickinson, San Jose, CA, USA) using the software CellQuest ${ }^{\mathrm{TM}}$ Pro by first scatter-gating 50000 events on the lymphocyte population. The percentages of $\mathrm{CD} 3$-positive, $\mathrm{CD} 4{ }^{+} \mathrm{CD} 8^{-}-$and $\mathrm{CD} 4^{-} \mathrm{CD} 8^{+}$cells in the lymphocyte population were then recorded.

\section{Lymphocyte Proliferation}

Culture of freshly isolated splenic MNC was performed in the presence of $10 \%$ of fetal bovine serum (FBS). Cells were plated at $2 \times 10^{6} \mathrm{cells} / \mathrm{ml}$ in flat-bottom 96-well culture plates in a volume of $100 \mu \mathrm{l}$ per well and incubated at $39^{\circ} \mathrm{C}$ in a humidified $5 \% \mathrm{CO}_{2}$ atmosphere. $\mathrm{T}$ cell proliferation was induced by Con A $(20$ or $40 \mu \mathrm{g} / \mathrm{ml}$, Wako Pure Chemical Industries, Osaka, Japan) or PHA (10 or $20 \mu \mathrm{g} / \mathrm{ml}$, Sigma, St. Lois, MO, USA) stimulation for 48 hours. Cell proliferation was measured using Cell Counting Kit-8 (Dojindo, Osaka, Japan) according to the manufacturer's guidelines. Result was expressed as the arbitrary unit on the basis of absorbance values (absorbance A $450 \mathrm{~nm}-\mathrm{A} 655 \mathrm{~nm}$ of cells activity cultured with Con A or PHA/absorbance $_{\mathrm{A} 450 \mathrm{~nm}-\mathrm{A} 655 \mathrm{~nm}}$ of cells activity cultured without Con A or PHA) of MNC from chicks fed the diet without Ax.

\section{Measurement of IL-2- like Activity}

The IL-2-like activity assay was carried out by a method based on $\mathrm{T}$ cell proliferation as described by Myers et al. (1992) with slight modification. Splenic MNC prepared from chicks fed on each diet were cultured at a concentration of $2 \times 10^{6}$ cells $/ \mathrm{m} l$ in RPMI-1640 medium, in the absence or presence of Con A $(20 \mu \mathrm{g} / \mathrm{ml})$. After 24 hours incubation at $39^{\circ} \mathrm{C}$ in a humidified $5 \% \mathrm{CO}_{2}$ atmosphere, the supernatants $(\mathrm{CM})$ were collected and the cells were removed. The $\mathrm{CM}$ was stored at $-80^{\circ} \mathrm{C}$ until assayed for IL-2-like activity. The responder cells were prepared as follows; after 2 $\times 10^{6}$ cells $/ \mathrm{ml}$ were incubated in the presence of ConA $(20 \mu \mathrm{g} / \mathrm{ml})$ for 24 hours at $39^{\circ} \mathrm{C}$ in a humidified $5 \% \mathrm{CO}_{2}$, the supernatants were discarded and the cells were resuspended in RPMI-1640 medium with 5\% FBS containing $0.05 \mathrm{M}$ alpha methyl mannoside (Sigma, St. Lois, MO, USA) for $30 \mathrm{~min}$ at $39^{\circ} \mathrm{C}$ under $5 \% \mathrm{CO}_{2}$. Fifty $\mu l$ containing $2 \times 10^{5}$ of the responder cells and $50 \mu l$ of $\mathrm{CM}$ previously prepared were added to each well of 96well flat bottom culture plates and incubated for 24 hours at $39^{\circ} \mathrm{C}$ in a humidified $5 \% \mathrm{CO}_{2}$ atmosphere. Cell proliferation was measured by an enzyme reduction assay using Cell Counting Kit-8 (Dojindo, Osaka, Japan) according to the manufacturer's guidelines. Result was expressed as the basis of arbitrary unit on the absorbance values (absorbance $_{\mathrm{A} 450 \mathrm{~nm}-\mathrm{A} 655 \mathrm{~nm}}$ of cells activity cultured with CM presence of Con A/absorbance ${ }_{A 450 \mathrm{~nm}-\mathrm{A} 655 \mathrm{~nm}}$ of cells activity cultured with $\mathrm{CM}$ absent from Con A).

\section{Total RNA Isolation and RT-PCR}

Total RNA was extracted from splenic MNC (2 $\mathrm{m} l$ containing $1 \times 10^{7}$ cells $/ \mathrm{ml}$ ) cultured in the absence or presence of Con A $(20 \mu \mathrm{g} / \mathrm{ml})$ for 6 hours. Cells were suspended $750 \mu l$ of TRIzol $^{\circledR}$-regents (Invitrogen, Corp., Carlsbad, CA, USA) and RNA extracted according to manufacturer's instructions. RNA pellets were washed once with $75 \%$ ethanol, air dried and dissolved in $20 \mu l$ of RNase-free $\mathrm{H}_{2} \mathrm{O}$. RNA concentrations were determined spectrophotometrically at absorbance $\mathbf{A}_{260 \mathrm{~nm}}$, and integrity was checked by electrophoresis $(100 \mathrm{~V}, 20 \mathrm{~min})$ in $0.8 \%$ agarose gels containing ethidium bromide. $5 \mu \mathrm{g}$ of total RNA was reverse-transcribed by M-MLV (Invitrogen, Corp., Carlsbad, CA, USA) in a $20 \mu \mathrm{l}$ reaction volume using oligo (deoxythymidine) ${ }^{15}$ primer according to the manufacturer instructions.

\section{Real Time PCR}

Real-time PCR was performed using a fluorescence temperature cycler (Bio-Rad Laboratories, Hercules, CA, USA) and SYBR Green I as a double-stranded DNA-specific binding dye, according to the manufacturer's instructions (Bio-Rad 
Laboratories, Hercules, CA, USA). Amplifications were carried out using 1.25 U TaKaRa Taq ${ }^{\mathrm{TM}}$ or 1.25 U TaKaRa Ex Taq ${ }^{\mathrm{TM}}$ (Takara Shuzo, Kyoto, Japan), $0.5 \mu \mathrm{M}$ of IL-2 and GAPDH primer, $10 \times$ TaKaRa Taq ${ }^{\mathrm{TM}}$ buffer [100 mM Tris-HCl (pH 8.3), $500 \mathrm{mM} \mathrm{KCl}, 1.5 \mathrm{mM} \mathrm{MgCl} 2$ ] or $10 \times \mathrm{TaKaRa}_{\mathrm{Ex}}$ Taq $^{\mathrm{TM}}$ buffer [2.0 $\mathrm{mM} \mathrm{MgCl}_{2}$ ], $0.05 \mu l 1: 100$ diluted SYBR Green I nucleic acid gel stain (BioWhittaker, Inc. Molecular Applications, Rockland, ME, USA), and $1 \mu l \mathrm{cDNA}$ was used in a total vol of $50 \mu \mathrm{l}$. The real-time PCR conditions were: preheat denature at $94^{\circ} \mathrm{C}$ for $3 \mathrm{~min}$, annealing at 58 (IL-2), 63 (IFN- $\gamma$ ) and $65^{\circ} \mathrm{C}$ (glyreralehyde-3phosphate dehyrogenase used as internal standard., GAPDH) for $1 \mathrm{~min}$, and extension at $72^{\circ} \mathrm{C}$ for 1 min. SYBR Green I fluorescence was detected at $72^{\circ} \mathrm{C}$ at the end of each cycle to monitor the amount of PCR product formed during that cycle. A melting curve analysis of the amplification products was performed at the end of the PCR run ; followed by gradual increase in temperature to $95^{\circ} \mathrm{C}$ at a rate of $0.05^{\circ} \mathrm{C} / \mathrm{sec}$ with continuous measurement of fluorescence to confirm amplification of specific transcripts. The melting temperature profile for all samples of IL-2, IFN- $\gamma$ and GAPDH, demonstrated single peaks at $85,87.5$ and $90.5^{\circ} \mathrm{C}$, respectively. At the end of each run, melting curve profiles were recorded. Oligonucleotide sequences of sense and antisense primers were as follows : IL2, estimated product size 428 bp (nucleotides from 39 to 466, GenBank Accession NO. AF017645); IFN- $\gamma$, estimated product size 288 bp (GenBank Accession NO. X99774) ; GAPDH, estimated product size $543 \mathrm{bp}$ (GenBank Accession NO. AF 047874). The specificity of the amplification product was further verified by electrophoresis on a $0.8 \%$ agarose-gel following a check of the DNA sequence. Results are presented as the ratio of IL2 and IFN- $\gamma$ to GAPDH to correct for differences in the amounts of template DNA used.

\section{Statistical Analysis}

Data were subjected to one-way analysis of variance (ANOVA) of SAS (SAS Institute, 1982. Cary, NC, USA). Mean values within the treatments were compared using Duncan's multiple range test when main effect was statistically significant $(\mathrm{P}<0.05)$. The analysis for body weight gain, feed intake, and feed efficiency and Ax intake was done based on cage replications. Results were expressed as the mean \pm standard deviation.

\section{Results}

Table 2 shows body weight gain, feed intake, feed efficiency and Ax intake in chicks fed diets containing 0, 20 or 100 ppm Ax for 7 days. Dietary supplementation for 7 days of Phaffia yeast to provide 20 or $100 \mathrm{ppm} \mathrm{Ax}$ had no significant effects on body weight gain, feed intake and feed efficiency when compared with the control group. Total Ax intake for 7 days was estimated 6.75 and $32.35 \mathrm{mg}$ in chicks fed on diets containing 20 and $100 \mathrm{ppm}$ Ax, respectively.

Fig. 1 shows percentages of CD3-, CD4- and CD 8-positive cells of $\mathrm{T}$ cells in splenic lymphocytes prepared from chicks fed on diets containing 0, 20 or $100 \mathrm{ppm}$ Ax for 7 days. Percentages of CD3positive cells was about $90 \%$ of total $\mathrm{T}$ cells in chicks fed the control diet, while those in chicks fed diets containing Ax was about 75\%. Lowering effect of dietary Ax on percentages of CD3-positive cells was statistically significant in the $100 \mathrm{ppm} A x$ groups, but not in $20 \mathrm{ppm}$ Ax groups. Percentages of CD8-positive cells in lymphocyte population were about $50 \%$ in all dietary groups and not affected by feeding Ax. Percentages of CD4-positive cells was significantly lower in chicks fed diet containing $20 \mathrm{ppm}$ Ax than those in chicks fed the control diet, but not in chicks fed diet containing

Table 2. Effect of feeding diets with dietary supplementation of astaxanthin (Ax 0, 20 or $100 \mathrm{ppm}$ ) for 7 days on growth performance in male broiler chicks

\begin{tabular}{ccccc}
\hline \hline $\begin{array}{c}\text { Added Ax to diet } \\
(\mathrm{ppm})\end{array}$ & $\begin{array}{c}\text { Body weight gain } \\
(\mathrm{g} / 7 \text { days })\end{array}$ & $\begin{array}{c}\text { Feed intake } \\
(\mathrm{g} / 7 \text { days })\end{array}$ & Gain to Feed & $\begin{array}{c}\text { Ax intake } \\
(\mathrm{mg} / 7 \text { days })\end{array}$ \\
\hline 0 & $269 \pm 11$ & $338 \pm 4$ & $0.796 \pm 0.026$ & 0 \\
20 & $270 \pm 9$ & $337 \pm 3$ & $0.801 \pm 0.028$ & $6.75 \pm 0.06$ \\
100 & $254 \pm 8$ & $324 \pm 2$ & $0.785 \pm 0.025$ & $32.35 \pm 0.20$ \\
\hline
\end{tabular}


100 ppm Ax.

Fig. 2 shows $\mathrm{T}$ cell proliferation stimulated by (A) Con A or (B) PHA in MNC of chicks fed diets containing Ax for 7 days. $\mathrm{T}$ cell proliferation in chick fed diet containing $20 \mathrm{ppm}$ Ax for 7 days was about 30\% greater than that in chicks fed on diets containing 0 or $100 \mathrm{ppm}$ Ax when Con A was used as a mitogen. Feeding the diet containing $100 \mathrm{ppm}$ Ax showed no changes in the proliferation by challenge of Con A at concentration of 20 and $40 \mu \mathrm{g} / \mathrm{ml}$ as compared to feeding the control diet. Feeding diets supplemented with Ax for 7 days significantly enhanced the proliferative responses of $\mathrm{T}$ cells to PHA, regardless of PHA concentration in the incubation medium and Ax concentration of diet.

Fig. 3 shows (A) IL-2-like activity, (B) IL-2 and (C) IFN- $\gamma$ mRNA expressions in MNC stimulated by Con $\mathrm{A}$ in chicks fed diets containing $\mathrm{Ax}$ for 7 days. IL-2-like activity was about 20\% lower in chicks fed diets containing Ax than that in chick fed the control diet, the lowering effect in chicks fed diet containing $20 \mathrm{ppm}$ Ax was statistically significant as compared with the control group. Expression of IL-2 mRNA was lower in splenocytes of
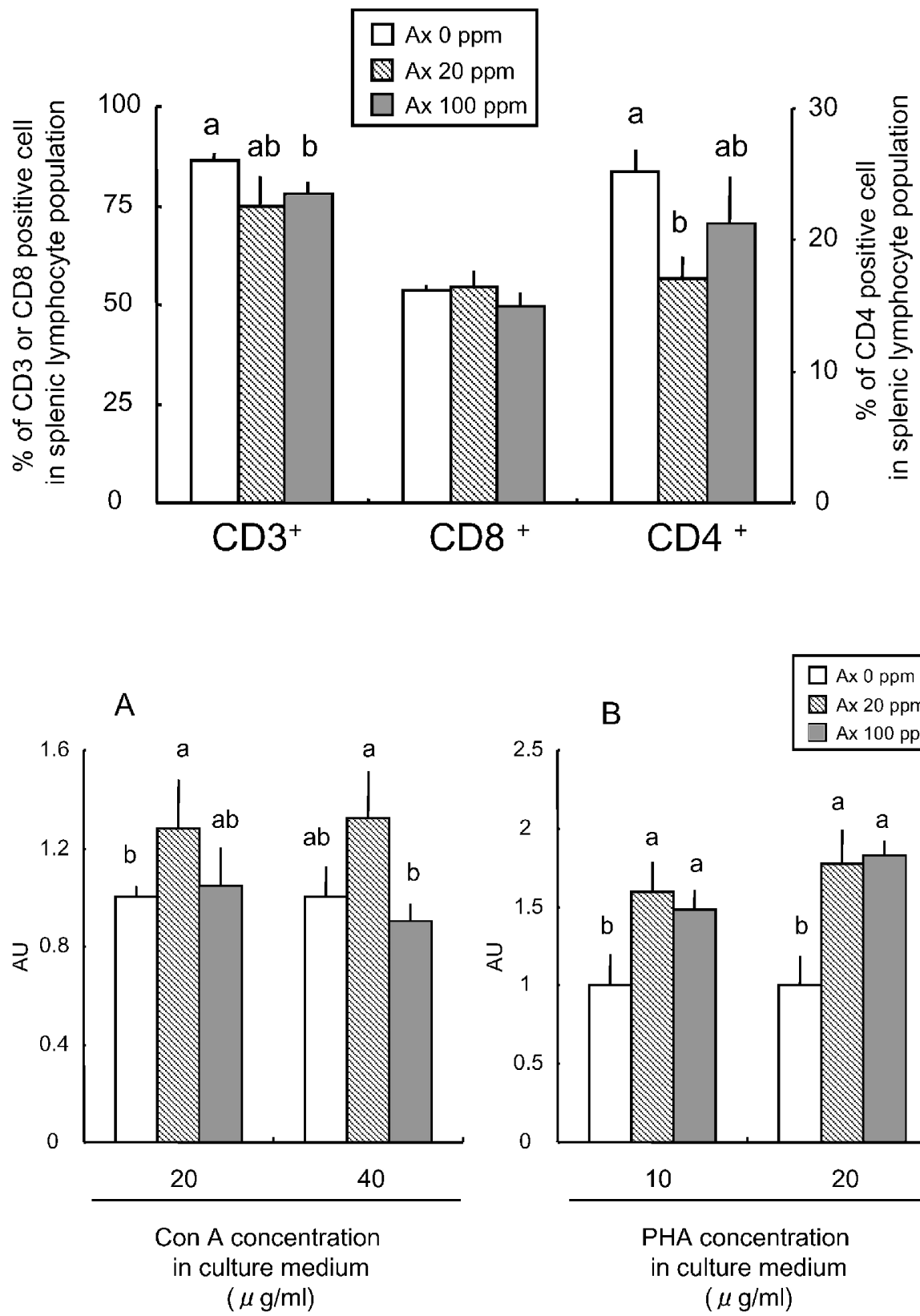

Fig. 1. Percentages of CD3-, CD 4- or CD8-positive cells in splenocytes of chicks fed diets containing 0,20 or $100 \mathrm{ppm}$ astaxanthin $(\mathrm{Ax})$ for 7 days. Each bar represents the mean and standard deviation from 4 individual chickens. Means with different scripts are significantly difference $(\mathrm{P}<0.05)$.

Fig. 2. $\mathrm{T}$ cell proliferation stimulated by (A) concanavalin $\mathrm{A}$ (Con A) or (B) phytohemagglutinin (PHA) in splenocytes of chicks fed diets containing 0,20 or $100 \mathrm{ppm}$ astaxanthin (Ax) for 7 days. AU was expressed as the basis of absorbance values (absorbance $_{\mathrm{A} 450 \mathrm{~nm}-\mathrm{A} 655 \mathrm{~nm}}$ of cells activity cultured with Con A or $\mathrm{PHA} /$ absorbance $_{\mathrm{A} 450 \mathrm{~nm}-\mathrm{A} 655 \mathrm{~nm}}$ of cells activity cultured without Con A or PHA) of MNC from chicks fed diet without Ax. Each bar represents the mean and standard deviation from 4 individual chickens. Means with different scripts are significantly difference $(\mathrm{P}$ $<0.05)$. 
A

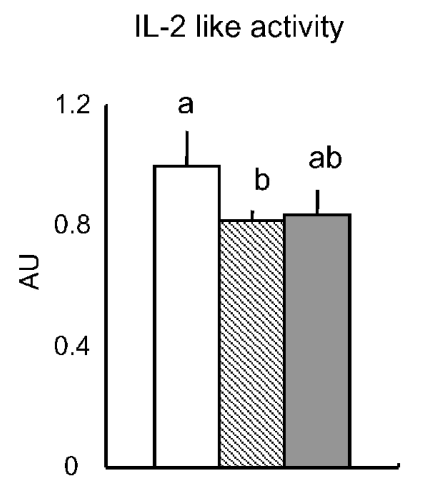

B

IL-2 mRNA expression

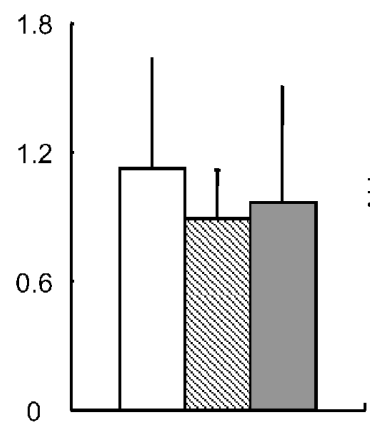

C

IFN- $\gamma$ mRNA expression

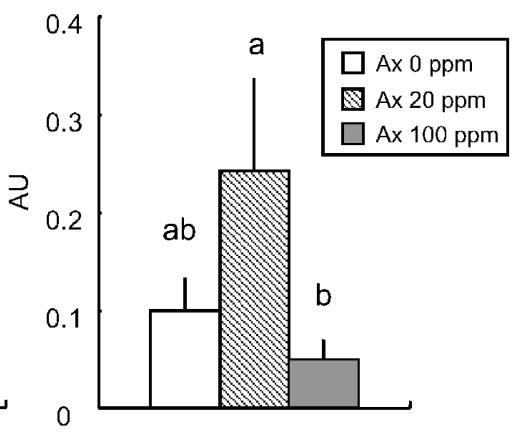

Fig. 3. Interleukin (IL)-2-like activity (A), expression of IL-2 mRNA (B) and interferon- $\gamma$ (IFN- $\gamma$ ) mRNA (C) in splenocytes of chicks fed diets containing 0,20 or $100 \mathrm{ppm}$ astaxanthin $(\mathrm{Ax})$ for 7 days. For measurement of IL-2-like activity, splenocytes were stimulated by Con A for 24 hours. For expression of IL- 2 mRNA and IFN- $\gamma$ mRNA, splenocytes were stimulated by Con A for 6 hours. AU for IL-2 like activity was expressed as the ratio of absorbance $_{\mathrm{A} 450 \mathrm{~nm}-\mathrm{A} 655 \mathrm{~nm}}$ of cells activity cultured with CM in presence of Con A/absorbance ${ }_{\mathrm{A} 450 \mathrm{~nm}-\mathrm{A} 655 \mathrm{~nm}}$ of cells activity cultured with $\mathrm{CM}$ in absence from Con A. AU for expression of IL-2 and IFN- $\gamma$ mRNA was expressed as IL-2 mRNA expression/GAPDH mRNA expression and IFN- $\gamma$ mRNA expression/GAPDH mRNA expression, respectively. Each bar represents the mean and standard deviation from 4 individual chickens. Means with different scripts are significantly difference $(\mathrm{P}<0.05)$.

chicks fed diets containing 20 and $100 \mathrm{ppm}$ Ax than those in chicks fed the control diet, but the effect was not statistically significant. Expression of IFN- $\gamma$ mRNA was 2.5 to 3 folds greater in chicks fed diet containing $20 \mathrm{ppm}$ Ax than those in chicks fed diets containing 0 or $100 \mathrm{ppm}$ Ax. Pattern of changes in the expression of IFN- $\gamma$ mRNA by feeding $\mathrm{Ax}$ was similar to that in the proliferative response of $\mathrm{MNC}$ to Con $\mathrm{A}$.

\section{Discussion}

The present study showed that feeding $20 \mathrm{ppm}$ Ax, but not $100 \mathrm{ppm} \mathrm{Ax}$, altered $\mathrm{T}$ cell subpopulation in spleen lymphocyte, suggesting that the modulation of lymphocytes by Ax varies with the dietary concentration and feeding $20 \mathrm{ppm}$ Ax probably modulates $\mathrm{T}$ cells differentiation. Percentages of CD4-positive cells were decreased and that of CD8positive cells was not affected by feeding the diet containing Ax $20 \mathrm{ppm}$. Thus Ax may be a novel nutrient to modify $\mathrm{T}$ cell differentiation in chicks, although it is not clear why the effect of Ax on T cell differentiation is not related with total $\mathrm{Ax}$ intake or dietary Ax concentration.

The present study also showed that $\mathrm{T}$ cell proliferation stimulated by Con A was enhanced by feeding the diet containing $20 \mathrm{ppm}$ Ax for 7 days and that by PHA was enhanced by feeding the diet containing 20 or $100 \mathrm{ppm} \mathrm{Ax}$. It has been reported that feeding Ax in mice enhanced lymphocyte proliferation against PHA, but not influence that against Con A and LPS (Chew et al., 1999). It has been reported that Con A mainly stimulates CD8positive $\mathrm{T}$ cells which specifically express at membrane of cytotoxic $\mathrm{T}$ cells, while PHA stimulates CD4-positive $\mathrm{T}$ cells which specifically express at membrane of helper $\mathrm{T}$ cells in chickens (Chan et al., 1988). Therefore, it is presumed that Ax pro- 
vided from Phaffia yeast stimulated proliferation of both cytotoxic and helper $\mathrm{T}$ cells in chick spleen.

IL-2 is an essential cytokine for fundamental immune processes and a potent growth factor for a variety of cell types, and plays key roles in $\mathrm{T}$ cell differentiation and function in avian species (Lillehoj et al., 1992). IFN- $\gamma$ serves as an important regulator in the activation of lymphocytes and monocytes (Lillehoj et al., 1992). Thus, it has been believed that IL- 2 and IFN- $\gamma$ are critical modulators in most immune responses including $\mathrm{T}$ cell proliferation. An enhancement of $\mathrm{T}$ cell proliferation, independent of an increase in IL-2 production, by Ax has been noted in mammals (Jyonouchi et al., 1991 ; Chew et al., 1999). Kim et al. (2000 a and b) reported that lutein, a family of xanthophyll same as $\mathrm{Ax}$, increased $\mathrm{T}$ cell proliferation but this effect was independent of IL-2 production in dogs and cats. The present study indicated that an enhancement of $\mathrm{T}$ cell proliferation by Ax appeared to be independent of IL-2 production in chicks when the cells were stimulated by Con A. The present experiment suggested that $\mathrm{T}$ cell proliferation by Ax was related to IFN- $\gamma$ mRNA expression rather than IL-2 production when chicks ( 7 days of age) were fed the diet containing $20 \mathrm{ppm}$ Ax for 7 days. However, it is unclear why the effect of $\mathrm{Ax}$ on $\mathrm{T}$ cell proliferation as well as $\mathrm{T}$ cell population is not dependent of dietary Ax concentration as mentioned above. Woodall et al. (1996) showed that dietary supplementation with $100 \mathrm{ppm}$ beta-carotene lowered plasma alpha-tocopherol level in male Leghorn chicks, suggesting that an excess intake of some carotenoids in chicks would inhibit absorption of alpha-tocopherol or normal metabolism of alpha-tocopherol. Since alpha-tocopherol is an important nutrient to maintain immune responses, the reduction of alpha-tocopherol intake and its deposition in organs should be associated with impaired immune response including the proliferative response of T cells (Erf et al., 1998 ; Leshchinsky and Klasing 2001). This will be one of the reasons that feeding the diet containing $100 \mathrm{ppm}$ Ax showed no effect on some of immune responses observed in this study. However, it is not always sufficient to explain the effect of $\mathrm{Ax}$ on $\mathrm{T}$ cell response against mitogen from this reason since feeding diets supplemented with $100 \mathrm{ppm}$ Ax for 7 days significantly enhanced the proliferative responses of $\mathrm{T}$ cells to
PHA. Thus further studies are needed for elucidation of immunomodulative effects of Ax on $\mathrm{T}$ cell population and responsiveness to antigen or mitogen.

\section{Acknowledgments}

We appreciate the Japan Poultry Science Association for their financial support to present a part of this study at XXII World's Poultry Congress in Istanbul, Turkey (2004).

\section{References}

Akiba Y and Matsumoto T. Effect of force-feeding and dietary cellulose on liver lipid accumulation and lipid composition of liver and plasma in growing chicks. Journal of Nutrition, 108 : 739-748. 1978.

Akiba Y, Sato K, Takahashi K, Takahashi Y, Furuki A, Kohashi S, Nishida H, Tsunekawa H, Hayasaka Y and Nagao H. Pigmentation of egg yolk with yeast Phaffia rhodozyma containing high concentration of astaxanthin in laying hens fed on a low-carotenoid diet. Japanese Poultry Science, 37 : 77-85. 2000.

Akiba Y, Sato K, Takahashi K, Matsushita K, Komiyama $\mathrm{H}$, Tsunekawa $\mathrm{H}$ and Nagao $\mathrm{H}$. Meat color modification in broiler chickens by feeding yeast Phaffia rhodozyma containing high concentration of astaxanthin. Journal of Applied Poultry Research, 10 : 154161. 2001.

Chan MM, Chen CH, Ager LL and Cooper MD. Identification of the avian homologues of mammalian CD4 and CD8 antigens. Journal of Immunology, $140: 2133^{-}$ 2138. 1988.

Chen CH, Agar LL, Gartland GL and Cooper MD. Identification of a T3/T cell receptor complex in chickens. Journal of Experimental Medicine, 164 : 375-380. 1986.

Cheng YH, Shen TF, Pang VF and Chen BJ. Effect of aflatoxin and carotenoids on growth performance and immune response in mule ducklings. Comparative Biochemistry and Physiology (C), 128 : 19-26. 2001.

Chew BP, Wong MW, Park JS and Wong TS. Dietary $\beta$-carotene and astaxanthin but not canthaxanthin stimulate splenocyte function in mice. Anticancer Research, 19 : 5223-5227. 1999.

Erf GF, Bottje WG, Bersi TK, Headrick MD and Fritts CA. Effects of dietary vitamin $\mathrm{E}$ on the immune system in broilers: altered proportions of CD4 T cells in the thymus and spleen. Poultry Science, 77 : 529-537. 1998.

Jyonouchi H, Hill RJ, Tomita Y and Good RA. Studies of immunomodulating actions of catotenoids. Effects of $\beta$-carotene and astaxanthin on murine lymphocyte functions and cell surface maker expression in in vitro culture system. Nutrition and Cancer, 16 : 93-105. 1991.

Jyonouchi H, Sun S, Tomita Y and Gross MD. Astaxanthin, a carotenoid without vitamin A activity, augments antibody responses in cultures including $\mathrm{T}$ - 
helper cell clones and suboptimal doses of antigen. Journal of Nutrition, 125 : 2483-2492. 1995.

Jyonouchi H, Sun S, Iijima K and Gross MD. Antitumor activity of astaxanthin and its mode of action. Nutrition and Cancer, $36: 59-65.2000$.

Kim HW, Chew BP, Wong TS, Park JS, Weng BC, Byrne KM, Hayek MG and Reinhart GA. Modulation of humoral and cell-mediated immune responses by dietary lutein in cats. Veterinary Immunology and Immunopathology, 73 : 331-341. 2000 a.

Kim HW, Chew BP, Wong TS, Park JS, Weng BC, Byrne KM, Hayek MG and Reinhart GA. Dietary lutein stimulates immune response in the canine. Veterinary Immunology and Immunopathology, $74: 315-327$. 2000 b.

Leshchinsky TV and Klasing KC. Relationship between the level of dietary vitamin $\mathrm{E}$ and the immune response of broiler chickens. Poultry Science, 80 : 1590-1599. 2001.
Lillehoj HS, Kaspers B, Jenkins MC and Lillehoj EP. Avian interferon and interleukin-2. A review by comparison with mammalian homologues. Poultry Science Reviews, $4: 67-85.1992$.

Myers TJ, Lillehoj HS and Fetter RH. Partial purification and characterization of chicken interleukin-2 activity. Veterinary and Immunology Immunopathology, 34 : 97-114. 1992.

Takahashi K, Watanabe M, Takimoto T and Akiba Y. Uptake and distribution of astaxanthin in several tissues and plasma lipoproteins in male broiler chickens fed a yeast (Phaffia Rhodozyma) with a high concentration of astaxanthin. British Poultry Science, 45 : 133-138. 2004.

Woodall AA, Britton G, Jackson MJ. Dietary supplementaion with cartenoids : effects on alpha-tocopherol levels and susceptibility of tissues to oxidative stress. British Journal of Nutrition, 76 : 307-317. 1996. 